https://doi.org/10.18778/1509-877X.2019.01.03

Artykuły

Joanna Rusek*

\title{
WYKORZYSTANIE KONCEPCJI SUBSTANCE Z PERSPEKTYWY MIĘDZYNARODOWYCH REGULACJI PODATKOWYCH
}

Streszczenie. Celem artykułu jest przedstawienie rozmaitych sposobów wykorzystania koncepcji treści ekonomicznej (substance) na gruncie międzynarodowym. Z tej perspektywy w pierwszej kolejności analizie zostały poddane prace prowadzone w ramach projektu BEPS. Rozważane było także posługiwanie się pojęciem substance przez Modelową Konwencję OECD. Biorąc pod uwagę powyższe regulacje, koncepcja treści - rozumianej jako tworzenie wartości przy uwzględnieniu rzeczywiście pełnionych funkcji, zaangażowanych aktywów, zatrudnionych pracowników, ponoszonego ryzyka różnego rodzaju - została uznana za szczególnie użyteczną dla przeciwdziałania negatywnemu zjawisku unikania opodatkowania.

Słowa kluczowe: unikanie opodatkowania, treść ekonomiczna, BEPS, Modelowa Konwencja OECD

1. WPROWADZENIE

Można zasadnie przyjąć, że współcześnie jednym z najistotniejszych wyzwań dla systemu podatkowego jest zapewnienie skutecznego poboru podatków i przeciwdziałanie zjawisku unikania opodatkowania. Wpływy z podatków stanowią dla budżetu państwa ważne źródło finansowania zadań publicznych, stąd ich utrzymanie na pewnym stabilnym poziomie jest absolutną koniecznością. Nie jest jednak także tajemnicą, że w erze globalizacji podatnicy - szczególnie przedsiębiorstwa międzynarodowe

* Doktor nauk prawnych, radca prawny i doradca podatkowy, manager w KPMG Tax M. Michna sp.k., e-mail: asiarusek@poczta.onet.pl 
- nie mają trudności z przenoszeniem swojej aktywności pomiędzy różnymi państwami i instrumentalnym nieraz wykorzystywaniem preferencyjnych rozwiązań oferowanych przez poszczególne jurysdykcje podatkowe. Tworzeniu rozbudowanych, wielopoziomowych struktur organizacyjnych niejednokrotnie nie towarzyszy przy tym jakakolwiek znacząca zmiana w faktycznie prowadzonej działalności gospodarczej. Dostrzegając powyższe zjawisko, władze skarbowe starają się doprowadzić do opodatkowania rzeczywiście dokonywanych przez podatników czynności / realizowanych transakcji, bez względu na obrane przez nich formy prawne. W konsekwencji na gruncie prawa podatkowego coraz istotniejszego znaczenia nabiera pojęcie treści ekonomicznej (ang. substance).

Generalnie pojęcie treści nie jest w prawie podatkowym zdefiniowane. Sama koncepcja treści - rozumianej ogólnie jako konieczność istnienia pewnej rzeczywistości gospodarczej - jest jednak szeroko wykorzystywana zarówno na poziomie krajowym, jak i międzynarodowym. Chodzi przy tym i o konkretne regulacje prawne (np. funkcjonująca w wielu krajach klazula ogólna przeciwko unikaniu opodatkowania), i o poglądy nie zawsze skodyfikowane, ale wynikające $\mathrm{z}$ dorobku orzecznictwa (np. doktryny orzecznicze przeciwko unikaniu opodatkowania: substance over form, business purpose itp.).

\section{Pojęcie treści w PROJEKCIE BEPS}

Rozważając zagadnienie z perspektywy międzynarodowej, na pierwszy plan wysuwają się prace prowadzone z inicjatywy OECD/G20 w ramach projektu BEPS (przeciwdziałanie zjawisku erozji podstawy opodatkowania i przenoszeniu zysku, ang. Base Erosion and Profit Shifting). Opublikowany przez OECD w dniu 19 lipca 2013 r. Plan Działań w zakresie BEPS (ang. Action Plan on Base Erosion and Profit Shifting) ${ }^{1}$ zawiera piętnaście różnych obszarów analizy, której efektem miało być wyposażenie władz państwowych w instrumenty pozwalające na zapobieganie nieuczciwemu unikaniu opodatkowania i transferowaniu zysków do rajów podatkowych. Z perspektywy koncepcji substance spośród wspomnianych obszarów na szczególną uwagę zasługują2:

1 Por. Action Plan on Base Erosion and Profit Shifting, OECD Publishing, Paris 2013.

2 Por. też M. Stewart, Abuse of Economic Substance in a Digital BEPS World, „Bulletin for International Taxation" June/July 2015, s. 399. 
- Działanie 5: efektywne zwalczanie szkodliwych praktyk podatkowych przy uwzględnieniu transparentności i treści (ang. Countering Harmful Tax Practices More Effectively, Taking into Account Transparency and Substance) $)^{3}$;

- Działanie 6: zapobieganie nadużyciom w wykorzystaniu udogodnień traktatowych (ang. Preventing the Granting of Treaty Benefits in Inappropriate Circumstances) ${ }^{4}$;

- Działania 8-10: zapewnienie, by rezultaty stosowania cen transferowych były zgodne z tworzeniem wartości dodanej (ang. Aligning Transfer Pricing Outcomes with Value Creation) ${ }^{5}$;

- Działanie 15: stworzenie wielostronnego instrumentu do wprowadzenia Planu Działań BEPS oraz modyfikacji istniejących umów o unikaniu podwójnego opodatkowania (ang. Multilateral Convention to Implement Tax Treaty Related Measures to Prevent BEPS) ${ }^{6}$.

W ramach Działania 5 uwaga została poświęcona stosowanym przez różne kraje preferencyjnym reżimom podatkowym (zwłaszcza w zakresie własności intelektualnej) ${ }^{7}$ oraz przesłankom traktowania takich reżimów jako szkodliwe. W celu przeciwdziałania praktykom nadużywania wspomnianych reżimów zwrócono uwagę, że korzystanie z jakichkolwiek preferencji podatkowych powinno być uzależnione od prowadzenia przez podatnika istotnej działalności (ang. substantial activity) w danym kraju (co pozostaje $\mathrm{w}$ zgodzie $\mathrm{z}$ jednym $\mathrm{z}$ założeń projektu BEPS, zgodnie z którym opodatkowanie powinno być przyporządkowane treści w taki sposób, aby uniemożliwić sztuczne transferowanie dochodu z kraju, w którym tworzona

3 Por. Countering Harmful Tax Practices More Effectively, Taking into Account Transparency and Substance, Action 5 - 2015 Final Report, OECD/G20 Base Erosion and Profit Shifting Project, OECD Publishing, Paris 2015.

4 Por. Preventing the Granting of Treaty Benefits in Inappropriate Circumstances, Action 6 - 2015 Final Report, OECD/G20 Base Erosion and Profit Shifting Project, OECD Publishing, Paris 2015.

5 Por Aligning Transfer Pricing Outcomes with Value Creation, Actions 8-10 - 2015 Final Reports, OECD/G20 Base Erosion and Profit Shifting Project, OECD Publishing, Paris 2015.

${ }^{6}$ Por. Developing a Multilateral Instrument to Modify Bilateral Tax Treaties, Action 15 - 2015 Final Report, OECD/G20 Base Erosion and Profit Shifting Project, OECD Publishing, Paris 2015.

7 Spośród 43 analizowanych krajów, których reżimy podatkowe zostały uznane za preferencyjne, w szesnastu preferencje dotyczyły właśnie własności intelektualnej. Por. Countering Harmful..., s. 10. 
jest wartość). Odnosząc powyższe do państw stosujących preferencyjne reżimy podatkowe dla własności intelektualnej (ang. intellectual property

- IP), przedstawiono trzy różne podejścia do wymogu wykazania przez podatnika istotnej działalności:

- $\quad$ podejście pierwsze - oparte na koncepcji tworzenia wartości, wymagające podjęcia przez podatnika określonej liczby znaczących działań rozwojowych w danym państwie;

- podejście drugie - oparte na mechanizmach charakterystycznych dla cen transferowych, uprawniające do zastosowania preferencji podatkowych do wszelkiego dochodu generowanego przez własność intelektualną pod pewnymi warunkami (ulokowanie przez podatnika w państwie oferującym preferencje określonego zakresu istotnych funkcji, posiadanie przez podatnika tytułu własności do aktywów uprawniających do stosowania preferencji oraz korzystanie przez podatnika z tych aktywów, ponoszenie przez podatnika ryzyka związanego ze wspomnianymi aktywami);

- $\quad$ podejście trzecie - przyjęte za obowiązujące - oparte na powiązaniu (ang. nexus) wysokości przyznanej przez dany kraj korzyści podatkowej z poniesionymi przez podatnika wydatkami na działalność w zakresie badania i rozwoju.

Zgodnie z trzecim przedstawionym wyżej podejściem w ramach Działania 5 podnoszono, że w odniesieniu do krajów stosujących preferencyjne reżimy podatkowe dla własności intelektualnej wymóg wykazania przez podatnika istotnej działalności wskazuje na związek pomiędzy wydatkami, aktywami stanowiącymi własność intelektualną oraz dochodami generowanymi przez tę własność. Konsekwentnie - odnosząc powyższe do krajów stosujących preferencyjne reżimy podatkowe niezwiązane $z$ własnością intelektualną - stwierdzono, że wymóg wykazania przez podatnika istotnej działalności także powinien wiązać dochód korzystający z preferencji z podstawowymi działaniami koniecznymi do wygenerowania tego dochodu. Rodzaje takich działań, uznawanych za podstawowe, zależałyby oczywiście od konkretnych przyznawanych przez dane państwo ulg podatkowych (korzystne reżimy dla centrów dystrybucyjnych i centrów usług, dla działalności finansowej i leasingowej, bankowej i ubezpieczeniowej, dla spółek holdingowych i inne).

Dalsze prace dotyczące Działania 5, prowadzone w ramach Forum do Szkodliwych Praktyk Podatkowych (ang. Forum on Harmful Tax Practices), doprowadziły do wydania w 2018 r. dokumentu w sprawie Wznowienia 
stosowania przesłanki istotnej działalności w odniesieniu do krajów niestosujących opodatkowania lub w których opodatkowanie ma jedynie charakter nominalny (ang. Resumption of Application of Substantial Activities Factor to No or only Nominal Tax Jurisdictions) $)^{8}$. Zgodnie z tym dokumentem wykazanie przez dany podmiot prowadzenia istotnej działalności wymaga:

- zatrudniania przez ten podmiot odpowiedniej liczby pełnoetatowych, wykwalifikowanych pracowników;

- $\quad$ ponoszenia określonych wydatków na działalność operacyjnąa;

- posiadania stosownych pomieszczeń i wyposażenia;

- $\quad$ posiadania kompetencji do podejmowania decyzji ${ }^{10}$.

W ramach Działania 6 punktem wyjścia było spostrzeżenie, że - zgodnie $\mathrm{z}$ założeniami projektu BEPS - poszczególne kraje powinny zmodyfikować istniejące regulacje podatkowe w taki sposób, aby ściślej powiązać powstawanie przychodu z działalnością ekonomiczną ten przychód generującą. Nadużywanie korzyści traktatowych, zwłaszcza w postaci tzw. kupczenia uprawnieniami umownymi przez osobę do tego nieuprawnioną (ang. treaty shopping), zostało bowiem wskazane jako jedno z podstawowych zagrożeń dostrzeganych przez BEPS ${ }^{11}$.

W ramach Działania 6 zaproponowanych zostało kilka instrumentów prawnych przeciwdziałających przyznawaniu korzyści podatkowych w niewłaściwych okolicznościach. Chodzi mianowicie o - opartą na teście głównego celu (ang. Principal Purpose Test - PPT) - ogólną klauzulę przeciwko nadużywaniu postanowień traktatowych oraz o tzw. klauzulę ograniczenia korzyści (ang. Limitation on Benefits - LOB). W odniesieniu do PPT przesłanką jego zastosowania jest stwierdzenie, że uzyskanie korzyści traktatowej było jednym $\mathrm{z}$ głównych celów (ang. one of the principal purposes) utworzenia danej struktury lub zawarcia transakcji. Ustalenie

8 Por. Resumption of application of substantial activities for no or nominal tax jurisdictions - BEPS Action 5, OECD, Paris 2018.

9 Ibidem, s. 11-12 oraz schemat na s. 15. We wspomnianym dokumencie wskazano w szczególności na konieczność rozróżnienia w ramach substantial activities czynności generujących dochody niezwiązane z korzystaniem z własności intelektualnej oraz czynności służących wykorzystywaniu IP. W odniesieniu do tych drugich wyjaśniono, że w przypadku krajów niestosujących opodatkowania (lub stosujących opodatkowanie wyłącznie nominalne) niemożliwe jest wykorzystanie przewidzianego w ramach Działania 5 podejścia nexus, stąd konieczne jest zastosowanie mechanizmu analogicznego jak dla czynności generujących dochody niezwiązane z korzystaniem z IP.

10 Ibidem, schemat na s. 15.

11 Por. Preventing the Granting..., s. 13. 
wspomnianego wyżej „jednego z głównych celów” powinno być przy tym dokonywane na podstawie obiektywnej analizy zamiarów wszystkich osób zaangażowanych w organizację danej struktury/transakcji lub będących jej stroną ( $\mathrm{z}$ uwzględnieniem intencji doradców i podatników) ${ }^{12}$. Z kolei zadaniem LOB jest ograniczenie możliwości korzystania z przywilejów traktatowych tym podmiotom, które nie spełniają warunków odpowiedniego powiązania - definiowanych przez kryterium charakteru prawnego tych podmiotów, ich struktury właścicielskiej oraz rodzaju prowadzonej działalności - z państwem rezydencji ${ }^{13}$.

W ramach Działania 6 odniesiono się także do krajowych klauzul ogólnych przeciwko unikaniu opodatkowania - zarówno skodyfikowanych, jak i funkcjonujących na podstawie doktryn orzeczniczych (doktryna economic substance, substance over form, business purpose itp.). Stwierdzono mianowicie, że klauzule te odgrywają istotną rolę w zapobieganiu nadużyciom postanowień traktatowych i zasadniczo ich stosowanie nie stoi w sprzeczności z umowami międzynarodowymi ${ }^{14}$.

W ramach Działań 8-10 uwaga została skierowana na problem niewłaściwego stosowania istniejących standardów w zakresie cen transferowych, co może prowadzić do sytuacji, w której alokacja zysku nie jest powiązana z działalnością ekonomiczną ten zysk generującą. Odniesiono się w szczególności do podstawowej dla cen transferowych zasady arm's length, wskazując, że choć praktyczna w zastosowaniu, jednak bazuje ona na alokacji pomiędzy podmiotami powiązanymi funkcji, aktywów i ryzyka, wynikającej z zawartych przez te podmioty umów (kontraktów), co czyni ją podatną na manipulacje. Efektem takich manipulacji może być właśnie sytuacja, w której rezultaty zastosowania zasady arm's length nie korespondują z rzeczywistą wartością tworzoną przez poszczególne podmioty wchodzące w skład międzynarodowej grupy, wynikającą z prowadzonej przez te podmioty działalności gospodarczej ${ }^{15}$. W sytuacji wystąpienia takich właśnie istotnych rozbieżności pomiędzy warunkami wynikającymi z umowy (kontraktu) a faktycznym zachowaniem podmiotów powiązanych przebieg transakcji powinien zostać odtworzony na podstawie funkcji rzeczywiście pełnionych przez te podmioty, aktywów rzeczywiście zaangażowanych

\footnotetext{
12 Por. M. Stewart, Abuse of Economic Substance..., s. 403.

13 Por. Preventing the Granting..., s. 9.

14 Por. M. Stewart, Abuse of Economic Substance..., s. 403.

15 Por. Aligning Transfer Pricing..., s. 9.
} 
oraz ryzyka rzeczywiście ponoszonego ${ }^{16}$. W ramach Działań 8-10 wskazano przy tym w sposób szczegółowy, według jakich zasad i przy uwzględnieniu jakich okoliczności ten faktyczny przebieg transakcji powinien być ustalany. Zaproponowana rewizja zasad odnoszących się do cen transferowych miałaby zagwarantować, że - w ramach grupy podmiotów powiązanych - zyski z działalności operacyjnej są alokowane do działalności gospodarczej je generującej.

$\mathrm{W}$ odniesieniu do cen transferowych zagadnienie treści pojawia się także w kontekście dokumentu OECD z lipca 2017 r. - tzw. Wskazówek $\mathrm{z}$ zakresu cen transferowych dla przedsiębiorstw międzynarodowych oraz administracji skarbowej (ang. Transfer Pricing Guidelines for Multinational Enterprises and Tax Administrations) ${ }^{17}$. Wydaje się, że pojęcie treści jest tam odnoszone do rzeczywistych warunków realizowanej transakcji, ocenianych przez pryzmat podziału pomiędzy stronami tej transakcji pełnionych funkcji, ponoszonego ryzyka oraz zaangażowanych aktywów ${ }^{18}$. Jeśli chodzi o podział funkcji, to zgodnie ze Wskazówkami OECD dla stwierdzenia, czy warunki transakcji zostały ustalone na zasadach rynkowych, decydujące znaczenie mają dwie kwestie: kompetencje pracowników wykonujących określone czynności / pełniących określone role oraz uprawnienia wspomnianych osób do podejmowania decyzji ${ }^{19}$. W odniesieniu do podziału ryzyka wskazuje się, że generalnie strony transakcji powinny ponosić takie ryzyko, nad którym mają relatywnie większą kontrolę. Pojęcie kontroli jest przy tym rozumiane jako możliwość podejmowania decyzji dotyczących podjęcia ryzyka oraz sposobów zarządzania tym ryzykiem ${ }^{20}$. Odnośnie do posiadanych aktywów, w szczególności niematerialnych, wskazuje się wreszcie, że najważniejsze czynności związane z ich wytwarzaniem, ulepszaniem, utrzymywaniem oraz ochroną powinny być wykonywane wewnętrznie przez pracowników danego przedsiębiorstwa ${ }^{21}$. W celu stwierdzenia, czy dana transakcja zawiera odpowiednią treść (substance)

16 Ibidem, s. 19.

17 Por. OECD Transfer Pricing Guidelines for Multinational Enterprises and Tax Administrations 2017, OECD Publishing, Paris 2017, dalej: Wskazówki OECD.

18 Por. Rozdział I Sekcja D.1 Wskazówek OECD.

19 J. Monsenego, The Substance Requirement in the OECD Transfer Pricing Guidelines: What Is the Substance of the Substance Requirement, „International Transfer Pricing Journal" January/February 2014, s. 11.

${ }^{20}$ Ibidem, s. 14.

21 Ibidem. s. 16. 
- wystarczającą do uznania jej za rynkową - Wskazówki OECD odwołują się także do kwestii dotyczących pracowników danego przedsiębiorstwa, zwłaszcza ich liczby oraz faktycznej lokalizacji ${ }^{22}$.

W ramach Działania 15 BEPS doszło wreszcie do opracowania Konwencji wielostronnej implementującej środki traktatowego prawa podatkowego mające na celu zapobieganie erozji podstawy opodatkowania i przenoszeniu zysku (tzw. Konwencja MLI), podpisanej w Paryżu 7 czerwca 2017 r. ${ }^{23}$ Artykuł 7 tej Konwencji stanowi implementację Działania 6 BEPS, wskazując wprowadzenie przez umawiające się państwa mechanizmów weryfikujących prawo do korzystania z przywilejów przewidzianych $\mathrm{w}$ dwustronnych umowach o unikaniu podwójnego opodatkowania w postaci klauzuli głównego celu lub klauzuli ograniczenia korzyści. Wprowadzenie tych mechanizmów umożliwia przyznanie preferencji podatkowych wyłącznie tzw. podmiotom uprawnionym (ang. qualified person), zdefiniowanym w Konwencji MLI. Wśród tych podmiotów można wskazać zwłaszcza spółki prowadzące aktywną działalność gospodarczą (ang. active conduct of a business).

Podsumowując, działania podjęte w ramach inicjatywy BEPS jednoznacznie wskazują, że współcześnie w międzynarodowym prawie podatkowym decydujące znaczenie przywiązuje się do aspektu ekonomicznego funkcjonowania podmiotów - tworzenia przez nie wartości przy uwzględnieniu rzeczywiście pełnionych funkcji, zaangażowanych aktywów, zatrudnionych pracowników oraz ponoszonego ryzyka. Przywiązywanie przez OECD szczególnej wagi do konieczności wykazania treści w rozmaitych przejawianych przez podatników aktywnościach wynika zresztą wprost $\mathrm{z}$ jednego $\mathrm{z}$ trzech filarów leżących u podstaw inicjatywy BEPS, formułowanego właśnie jako wzmocnienie wymogów dotyczących treści (ang. reinforcing substance requirements) $\mathrm{w}$ ramach istniejących standardów międzynarodowych ${ }^{24}$.

\section{Ibidem, s. 18.}

${ }^{23}$ Multilateral Convention to Implement Tax Treaty Related Measures to Prevent Base Erosion and Profit Shifting, http://www.oecd.org/tax/treaties/multilateral-convention-toimplement-tax-treaty-related-measures-to-prevent-BEPS.pdf (dostęp: 4.02.2020).

${ }^{24}$ Por. Action Plan..., s. 13; zob. też R. Savoia, Y. Hurdowar, Switzerland: Embracing the worldwide trend of increasing substance requirements, „International Tax Review”, https://www.internationaltaxreview.com/article/b1f9jxz7hbz15p/switzerland-embracingthe-worldwide-trend-of-increasing-substance-requirements (dostęp: 4.02.2020). 


\section{Pojęcie treści w Modelowej Konwencji OECD}

Niezależnie od inicjatywy BEPS już wcześniej koncepcja substance - choć nienazwana - funkcjonowała na gruncie Modelowej Konwencji OECD w sprawie zapobieżenia podwójnemu opodatkowaniu w zakresie podatków od dochodu i majątku ${ }^{25}$. Na wspomnianej koncepcji jest oparte zwłaszcza pojęcie tzw. miejsca faktycznego zarządu (ang. place of effective management) podmiotów posiadających podwójną rezydencję podatkową czy instytucja tzw. osoby uprawnionej (do dywidend, odsetek, należności licencyjnych, ang. beneficial owner).

Jeśli chodzi o pierwszą wspomnianą wyżej regulację, to zgodnie z art. 4 ust. 1 Modelowej Konwencji osoba (niebędąca osobą fizyczną) mająca siedzibę w umawiającym się państwie oznacza każdą osobę, która - zgodnie z prawem tego państwa - podlega tam opodatkowaniu ze względu na jej siedzibę zarządu albo inne kryterium o podobnym charakterze. W myśl ust. 3 tego przepisu natomiast, jeżeli osoba (niebędąca osobą fizyczną) ma siedzibę w obu umawiających się państwach, rezydencja podatkowa tej osoby jest uzgadniana przez właściwe organy podatkowe obu państw przy uwzględnieniu miejsca jej faktycznego zarządu, inkorporacji oraz wszelkich innych istotnych okoliczności.

Pojęcie miejsca faktycznego zarządu nie zostało zdefiniowane w samej treści Modelowej Konwencji. Zgodnie natomiast ze wskazówkami zawartymi w Komentarzu ${ }^{26}$ przy podejmowaniu rozstrzygnięcia odnośnie do rezydencji podatkowej danego podmiotu (niebędącego osobą fizyczną) organy podatkowe powinny brać pod uwagę rozmaite okoliczności, a zwłaszcza:
a) miejsce, w którym zazwyczaj odbywają się spotkania rady dyrektorów lub innego podobnego organu danego podmiotu;
b) miejsce, w którym dyrektor generalny danego podmiotu oraz inni dy- rektorzy zazwyczaj wykonują swoje zadania;
c) miejsce, w którym wykonywany jest główny zarząd bieżącymi sprawa- mi danego podmiotu;
d) miejsce, w którym jest zlokalizowana siedziba danego podmiotu;
e) reżim prawny, który ma zastosowanie przy ocenie statusu prawnego danego podmiotu;
f) miejsce, w którym jest prowadzona księgowość danego podmiotu ${ }^{27}$.

25 Por. Model Tax Convention on Income and on Capital: Condensed Version 2017, OECD Publishing, Paris 2017, dalej: Modelowa Konwencja.

${ }^{26}$ Komentarz do Modelowej Konwencji, dalej: Komentarz.

27 Por. Komentarz, uwagi do art. 4 pkt 24.1. 
Analiza tych przesłanek wskazuje jednoznacznie, że przy rozstrzyganiu kwestii rezydencji podatkowej danego podmiotu decydującego znaczenia nie mają okoliczności formalne, takie jak siedziba statutowa tego podmiotu czy jego wpisanie do rejestru przedsiębiorców określonego państwa. Wręcz przeciwnie, wymienione okoliczności są drugorzędne w sytuacji, gdy badany podmiot nie posiada w danym kraju faktycznej obecności, wszystkie bowiem istotne decyzje go dotyczące są podejmowane $\mathrm{z}$ terytorium innego państwa. Przepisy Modelowej Konwencji dotyczące osoby mającej siedzibę w umawiającym się państwie wymagają zatem czegoś więcej niż dochowania formy niezbędnej do założenia określonego podmiotu w danym państwie - wymagają mianowicie wyposażenia tego podmiotu w rzeczywisty czynnik ludzki, mający faktyczne kompetencje sprawcze, w pewną strukturę organizacyjną, a więc w określoną treść.

Podobnie jak pojęcie miejsca faktycznego zarządu, także pojęcie osoby uprawnionej nie zostało zdefiniowane w samej treści Modelowej Konwencji. Opierając się natomiast na uwagach zawartych w Komentarzu ${ }^{28}$, można stwierdzić, że podmiot otrzymujący dywidendy, odsetki czy należności licencyjne nie jest traktowany jako osoba uprawniona do tych płatności w sytuacji, gdy de facto nie otrzymuje ich "dla siebie” (prawo danego podmiotu do dysponowania otrzymanymi płatnościami jest ograniczone, podmiot ten jest bowiem zobowiązany do dalszego przekazania tych płatności do innego podmiotu). Zgodnie z poglądem prezentowanym w literaturze osobą uprawnioną jest osoba, której można przypisać więcej niż innym osobom cech charakterystycznych dla prawa własności. Dla potrzeb prawa międzynarodowego przez atrybuty prawa własności należy przy tym rozumieć m.in. prawo do posiadania, korzystania, zarządzania, zbycia, zużycia, utracenia czy zniszczenia ${ }^{29}$. Biorąc pod uwagę powyższe, należy stwierdzić, że na gruncie Modelowej Konwencji dla korzystania z przewidzianych tam przywilejów podatkowych konieczne jest wyposażenie danego podmiotu (odbiorcy dywidend, odsetek czy należności licencyjnych) w faktyczne władztwo nad uzyskiwanymi płatnościami, co z kolei implikuje rzeczywisty (a nie tylko formalny) byt tego podmiotu.

Postanowienia Modelowej Konwencji OECD zawierają ponadto pewne regulacje wyrażające wprost zasadę przewagi treści nad formą (ang. substance

28 Por. Komentarz, np. uwagi do art. 10 pkt 12.4.

29 Por. Ch. P. du Toit, Beneficial Ownership of Royalties in Bilateral Tax Treaties, IBFD, Amsterdam 1999, s. 201 i n. 
over form). Przykładowo w myśl definicji zawartej w art. 10 ust. 3 Modelowej Konwencji przez dywidendę należy zasadniczo rozumieć dochód $\mathrm{z}$ akcji, praw do udziału w zysku oraz innych praw w spółce, traktowanych podobnie dla celów podatkowych. Jednakże zgodnie z uwagami zawartymi w Komentarzu ${ }^{30}$ art. 10 Modelowej Konwencji odnosi się nie tylko do dywidend jako takich, ale również do odsetek od pożyczek w takim zakresie, w jakim pożyczkodawca efektywnie uczestniczy w ryzyku ponoszonym przez spółkę, tj. kiedy zwrot pożyczki w dużym stopniu jest uzależniony od powodzenia prowadzonej przez spółkę działalności gospodarczej. Innymi słowy, Komentarz stanowi, że pod pewnymi warunkami odsetki mogą być traktowane jako dywidenda dla celów podatkowych ${ }^{31}$. Analogiczna konkluzja pozostaje aktualna dla definicji odsetek zawartej w art. 11 ust. 3 Modelowej Konwencji ${ }^{32}$. Należy ponadto zwrócić uwagę, że zgodnie z wyjaśnieniami zawartymi w Komentarzu ${ }^{33}$ definicja odsetek co do zasady nie obejmuje płatności dokonywanych w ramach niektórych typów niestandardowych instrumentów finansowych, w których brak bazowego długu (np. kontrakty swap na stopach procentowych). Definicja odsetek będzie jednak miała zastosowanie $\mathrm{w}$ takim zakresie, $\mathrm{w}$ jakim - na podstawie zasady substance over form, abuse of rights albo innej podobnej doktryny - zostanie uznane, że pożyczka faktycznie istnieje. Podejście zgodne z zasadą substance over form jest możliwe także na gruncie art. 11 ust. 6 Modelowej Konwencji, dotyczącego sytuacji, w której - w wyniku szczególnych powiązań pomiędzy podmiotami - kwota wypłacanych odsetek przekracza kwotę, która byłaby uzgodniona pomiędzy podmiotami niepowiązanymi. Zgodnie ze wskazówkami zawartymi w Komentarzu ${ }^{34}$ w celu właściwego opodatkowania takiej „nadwyżki” jej natura powinna zostać ustalona na podstawie okoliczności każdej sprawy. Analogiczna sytuacja dotyczy „nadwyżki” wypłacanych w wyniku powiązań pomiędzy podmiotami należności licencyjnych ${ }^{35}$.

Podejście zgodne z zasadą substance over form jest widoczne także przy identyfikowaniu rzeczywistego pracodawcy na potrzeby art. 15 ust. 2 lit. b

30 Por. Komentarz, uwagi do art. 10 pkt 25.

31 Por. B. Kosters, Substance over Form under Tax Treaties, „Asia-Pacific Tax Bulletin” styczeń/luty 2013, s. 7.

32 Por. Komentarz, uwagi do art. 11 pkt 19.

33 Por. Komentarz, uwagi do art. 11 pkt 21.1.

34 Por. Komentarz, uwagi do art. 11 pkt 35.

35 Por. art. 12 ust. 4 Modelowej Konwencji oraz Komentarz, uwagi do art. 12 pkt 25. 
Modelowej Konwencji, w przypadkach tzw. międzynarodowego wynajmu pracowników (ang. hiring-out of labour) ${ }^{36}$. Zgodnie z wyjaśnieniami przedstawionymi w Komentarzu ${ }^{37}$ w wielu krajach zostały wypracowane rozmaite kryteria i zasady orzecznicze (np. zasada substance over form) umożliwiające rozróżnienie sytuacji, w których czynności wykonywane przez osobę fizyczną na rzecz przedsiębiorstwa powinny być traktowane jako świadczone $\mathrm{w}$ ramach umowy o pracę (ang. contract of service) lub w ramach umowy o świadczenie usług (and. contract for service). Powyższe mechanizmy, wypracowane na gruncie krajowym, zachowują aktualność na potrzeby stosowania postanowień art. 15 ust. 2 lit. b i c Modelowej Konwencji. Nawet jednak w sytuacji, gdy regulacje krajowe nie przewidują możliwości kwestionowania formalnego stosunku umownego między stronami i w konsekwencji uznania, że usługi świadczone na rzecz krajowego przedsiębiorcy przez osobę fizyczną formalnie zatrudnioną u zagranicznego przedsiębiorcy są de facto świadczone na rzecz tego krajowego przedsiębiorcy w ramach stosunku pracy, odmowa zastosowania korzystnych postanowień art. 15 ust. 2 Modelowej Konwencji jest możliwa w przypadkach nadużyć3 ${ }^{38}$. Komentarz wskazuje przy tym listę okoliczności, które mogą być istotne w celu ustalenia, że rzeczywistym pracodawcą nie jest podmiot formalnie zatrudniający pracownika, lecz podmiot, na rzecz którego są świadczone usługi ${ }^{39}$. Wspomniane okoliczności - poza porównaniem charakteru czynności wykonywanych przez pracownika z przedmiotem działalności formalnego pracodawcy i faktycznego usługobiorcy - dotyczą tego:

a) kto jest upoważniony do instruowania pracownika odnośnie do sposobu wykonywania pracy;

b) kto sprawuje kontrolę i ponosi odpowiedzialność za miejsce wykonywania pracy;

c) czy usługobiorca jest bezpośrednio obciążany przez formalnego pracodawcę wynagrodzeniem pracownika;

d) kto dostarcza pracownikowi narzędzia i materiały konieczne w celu wykonywania pracy;

e) kto określa liczbę pracowników koniecznych do wykonania danej pracy i ich kwalifikacje;

\footnotetext{
36 Por. B. Kosters, Substance over Form..., s. 8.

37 Por. Komentarz, uwagi do art. 15 pkt 8.4 .

38 Por. Komentarz, uwagi do art. 15 pkt 8.8 .

39 Por. Komentarz, uwagi do art. 15 pkt 8.14.
} 
f) kto jest upoważniony do wskazania konkretnego pracownika do wykonania danej pracy, a także zakończenia nawiązanej w tym celu formalnej umowy;

g) kto jest upoważniony do stosowania wobec pracownika sankcji dyscyplinarnych;

h) kto określa rozkład czasu pracy oraz sposób korzystania z urlopu przez pracownika.

Podsumowując, wskazówki zawarte w Komentarzu jednoznacznie potwierdzają, że stosowanie postanowień opartych na Modelowej Konwencji umów w sprawie unikania podwójnego opodatkowania powinno następować z uwzględnieniem rzeczywistej treści analizowanych transakcji.

\section{SPOSObY FORMUŁOWANIA KRYTERIUM TREŚCI}

W literaturze wskazuje się, że na gruncie prawa międzynarodowego kryterium treści jest zasadniczo formułowane na dwa sposoby:

- poprzez wskazanie konkretnych warunków, które muszą zostać spełnione w celu skorzystania $\mathrm{z}$ danego uprawnienia lub uniknięcia zastosowania mechanizmu sankcyjnego, albo

- poprzez wskazanie szczegółowych, niemniej wciąż abstrakcyjnych kryteriów pomagających ocenić (jednak nie przesądzających), czy wymóg treści został spełniony ${ }^{40}$.

Przykładem pierwszego podejścia jest przewidziany w niektórych umowach o unikaniu podwójnego opodatkowania zawieranych przez Stany Zjednoczone test siedziby głównej (ang. headquarters test) ${ }^{41}$. Zapis taki znalazł się m.in. w nowej umowie z dnia 13 lutego 2013 r. zawartej z Polską $^{42}$. Zgodnie $\mathrm{z}$ art. 22 ust. 5 u.p.o. z przywilejów umownych zarezerwowanych, co do zasady, dla osób mających siedzibę w umawiającym się państwie mogą skorzystać również osoby pełniące funkcję siedziby głównej

${ }^{40}$ Por. J. Monsenego, The Substance Requirement..., s. 20.

41 Ibidem.

42 Konwencja między Rzecząpospolitą Polską a Stanami Zjednoczonymi Ameryki w sprawie unikania podwójnego opodatkowania i zapobiegania uchylaniu się od opodatkowania w zakresie podatków od dochodu, https://www.podatki.gov.pl/media/1910/20130213 konwencj_usa_pl.pdf (dostęp: 4.02.2020), dalej: u.p.o. Obecnie Konwencja ta jest nieobowiązująca, ponieważ została ratyfikowana tylko przez stronę polską (https://www. podatki.gov.pl/podatkowa-wspolpraca-miedzynarodowa/wykaz-umow-o-unikaniu -podwojnego-opodatkowania/ (dostęp: 4.02.2020),. 
(ang. headquarters company) dla wielonarodowej grupy przedsiębiorców. Dana osoba jest uważana za siedzibę główną wyłącznie w przypadku, gdy:

a) wykonuje istotną część całkowitego nadzoru oraz administrowania grupą, co może obejmować finansowanie grupy, jednakże nie może się do niego ograniczać;

b) grupa przedsiębiorstw składa się z przedsiębiorstw mających siedzibę, oraz aktywnie zaangażowanych w działalność gospodarczą, w co najmniej pięciu państwach, a działalność gospodarcza prowadzona w każdym z tych pięciu państw (lub pięciu grup państw) generuje co najmniej $10 \%$ dochodu brutto grupy;

c) działalność gospodarcza prowadzona w jakimkolwiek państwie innym niż umawiające się państwo, w którym spółka pełniąca funkcję siedziby głównej ma siedzibę, generuje mniej niż 50\% dochodu brutto grupy;

d) nie więcej niż 25\% jej dochodu brutto zostało uzyskane w drugim umawiającym się państwie;

e) osoba ta ma i wykonuje niezależną, uznaniową władzę podczas pełnienia funkcji, o których mowa w literze a);

f) osoba ta podlega takim samym zasadom opodatkowania w państwie swojej siedziby jak osoby, o których mowa w art. 22 ust. 4 u.p.o. (osoby uprawnione do korzystania z przywilejów umownych ze względu na aktywne prowadzenie handlu lub działalności gospodarczej);

g) dochód uzyskany w drugim umawiającym się państwie został osiągnięty w związku z aktywną działalnością gospodarczą, o której mowa w literze b), lub wynika z niej.

Drugie $\mathrm{z}$ wymienionych podejść zostało przykładowo zastosowane w przedstawionym już wcześniej teście rzeczywistego pracodawcy ${ }^{43}$. Uregulowanie to zawiera wiele szczegółowych, jednak nadal dość abstrakcyjnych przesłanek ułatwiających stwierdzenie, kto jest rzeczywistym pracodawcą danego pracownika, nie dając jednak w tym zakresie konkretnej odpowiedzi. Innym przykładem zastosowania tego podejścia jest - także omawiany już wcześniej - test miejsca faktycznego zarządu ${ }^{44}$.

Oceniając przydatność obu zaprezentowanych wyżej podejść, wydaje się, że pierwsze może się okazać użyteczne w przypadku konieczności

${ }^{43}$ Por. Komentarz, uwagi do art. 15 ust. 2 Modelowej Konwencji, pkt 8.14; J. Monsenego, The Substance Requirement..., s. 21.

${ }_{44}$ Por. Komentarz, uwagi do art. 4 ust. 3 Modelowej Konwencji, pkt 24.1; J. Monsenego, The Substance Requirement..., s. 21. 
jednoznacznego rozstrzygnięcia, czy np. dany podmiot jest uprawniony do określonych przywilejów / podlega określonym ograniczeniom. Podejście to wymaga jednak każdorazowo wskazania bardzo konkretnych przesłanek, adekwatnych do badanych okoliczności, a zatem jest obarczone dużą kazuistyką. Z tej perspektywy podejście drugie wydaje się bardziej uniwersalne - łatwiejsze do uregulowania od strony formalnej, a jednocześnie pozostawiające więcej swobody na ocenę realiów danej indywidualnej sprawy.

\section{Podsumowanie}

Obecnie można zasadnie uznać, że przeciwdziałanie negatywnemu zjawisku unikania podwójnego opodatkowania nie może następować wyłącznie na podstawie wybranych przez dany podmiot form prawnych prowadzenia działalności / realizowania transakcji, z pominięciem ich rzeczywistej treści. Z perspektywy międzynarodowej zagadnienie to zostało dostrzeżone zwłaszcza $\mathrm{w}$ toku prac prowadzonych $\mathrm{w}$ ramach projektu BEPS, stając się jednym $\mathrm{z}$ trzech filarów leżących u podstaw tej inicjatywy. Koncepcja treści - rozumianej z perspektywy ekonomicznej jako tworzenie wartości, przy uwzględnieniu rzeczywiście pełnionych funkcji, zaangażowanych aktywów, zatrudnionych pracowników, ponoszonego ryzyka - wydaje się przy tym na tyle uniwersalna, że możliwa do zastosowania w wielu różnych gałęziach prawa podatkowego.

\section{BiBLIOGRAFIA}

Action Plan on Base Erosion and Profit Shifting, OECD Publishing, Paris 2013.

Aligning Transfer Pricing Outcomes with Value Creation, Actions 8-10 - 2015 Final Reports, OECD/G20 Base Erosion and Profit Shifting Project, OECD Publishing, Paris 2015.

Countering Harmful Tax Practices More Effectively, Taking into Account Transparency and Substance, Action 5 - 2015 Final Report, OECD/G20 Base Erosion and Profit Shifting Project, OECD Publishing, Paris 2015.

Developing a Multilateral Instrument to Modify Bilateral Tax Treaties, Action 15 - 2015 Final Report, OECD/G20 Base Erosion and Profit Shifting Project, OECD Publishing, Paris 2015.

Konwencja między Rzecząpospolitą Polską a Stanami Zjednoczonymi Ameryki w sprawie unikania podwójnego opodatkowania i zapobiegania uchylaniu się od opodatkowania w zakresie podatków od dochodu, https://www.podatki.gov.pl/media/ 1910/20130213_konwencj_usa_pl.pdf (dostęp: 4.02.2020). 
Kosters B., Substance over Form under Tax Treaties, „Asia-Pacific Tax Bulletin” styczeń/ luty 2013.

Model Tax Convention on Income and on Capital: Condensed Version 2017, OECD Publishing, Paris 2017.

Monsenego J., The Substance Requirement in the OECD Transfer Pricing Guidelines: What Is the Substance of the Substance Requirement, „International Transfer Pricing Journal” January/February 2014.

Multilateral Convention to Implement Tax Treaty Related Measures to Prevent Base Erosion and Profit Shifting, http://www.oecd.org/tax/treaties/multilateral-convention-toimplement-tax-treaty-related-measures-to-prevent-BEPS.pdf (dostęp: 4.02.2020).

OECD Transfer Pricing Guidelines for Multinational Enterprises and Tax Administrations 2017, OECD Publishing, Paris 2017.

Preventing the Granting of Treaty Benefits in Inappropriate Circumstances, Action 6 - 2015 Final Report, OECD/G20 Base Erosion and Profit Shifting Project, OECD Publishing, Paris 2015.

Resumption of application of substantial activities for no or nominal tax jurisdictions - BEPS Action 5, OECD, Paris 2018.

Savoia R., Hurdowar Y., Switzerland: Embracing the worldwide trend of increasing substance requirements, „International Tax Review”, https://www.internationaltaxreview.com/ article/b1f9jxz7hbz15p/switzerland-embracing-the-worldwide-trend-of-increasingsubstance-requirements (dostęp: 4.02.2020).

Stewart M., Abuse of Economic Substance in a Digital BEPS World, „Bulletin for International Taxation" June/July 2015.

Toit du Ch. P., Beneficial Ownership of Royalties in Bilateral Tax Treaties, IBFD, Amsterdam 1999.

\section{USE OF THE CONCEPT OF ECONOMIC SUBSTANCE FROM THE PERSPECTIVE OF INTERNATIONAL TAX REGULATIONS}

Summary. The aim of this article is to demonstrate different ways in which the concept of economic substance is used on an international basis. From that perspective the outcomes of the BEPS project were firstly examined. Another area of interest was the usage of the concept of economic substance by the OECD Model Tax Convention. Bearing in mind the above works the concept of economic substance - understood as creation of value basing on really performed functions, engaged assets and employees as well as borne risks - was found particularly useful for the purpose of counteracting tax avoidance.

Keywords: tax avoidance, economic substance, BEPS, OECD Model Tax Convention 